\title{
Bivalves of the São Sebastião Channel, north coast of the São Paulo State, Brazil
}

\author{
Lenita de Freitas Tallarico ${ }^{1 *}$, Flávio Dias Passos ${ }^{2}$, Fabrizio Marcondes Machado ${ }^{3}$, Ariane Campos ${ }^{1}$, \\ Shirlei Maria Recco-Pimentel ${ }^{1}$ and Gisele Orlandi Introíni ${ }^{1,4}$ \\ 1 Universidade Estadual de Campinas, Instituto de Biologia, Departamento de Biologia Estrutural e Funcional. R. Charles Darwin, s/n - Bloco N \\ Caixa Postal 6109. CEP 13083-863. Campinas, SP, Brazil. \\ 2 Universidade Estadual de Campinas, Instituto de Biologia, Departamento de Biologia Animal. Rua Monteiro Lobato, 255, Caixa Postal 6109. \\ CEP 13083-970. Campinas, SP, Brazil. \\ 3 Programas de Pós-Graduação em Ecologia e Biologia Animal, Instituto de Biologia, Universidade Estadual de Campinas. R. Bertrand Russell, s/n, \\ Caixa Postal 6109, CEP 13083-970. Campinas, SP, Brazil. \\ 4 Universidade Federal de Ciências da Saúde de Porto Alegre, Departamento de Ciências Básicas da Saúde. R. Sarmento Leite, 245. CEP 90050-170. \\ Porto Alegre, RS, Brazil. \\ * Corresponding author. E-mail: letallarico@gmail.com
}

\begin{abstract}
The north coast of the São Paulo State, Brazil, presents great bivalve diversity, but knowledge about these organisms, especially species living subtidally, remains scarce. Based on collections made between 2010 and 2012 , the present work provides a species list of bivalves inhabiting the intertidal and subtidal zones of the São Sebastião Channel. Altogether, 388 living specimens were collected, belonging to 52 species of 34 genera, grouped in 18 families. Tellinidae, Veneridae, Semelidae, Ungulinidae, Mactridae, Solecurtidae, Corbulidae, Cardiidae, Lucinidae, Cooperellidae, Nuculidae, Psammobiidae, Donacidae, Solenidae, Periplomatidae, Thraciidae and Arcidae were the most representative families in this collection. Among the identified species, Caryocorbula caribaea, Codakia pectinella and Diplodonta punctata were intertidally abundant, while Macoma uruguayensis and Pitar fulminata were subtidally abundant.
\end{abstract}

\section{INTRODUCTION}

The municipalities of São Sebastião and Ilhabela are within an area of important biodiversity along northern coast of São Paulo State. Between the continent and Ilhabela island is the São Sebastião Channel (Figure 1). In this area, marine communities have been irreversibly altered because of exponential urban growth and anthropogenic influence in coastal zones. The commercial harbor at São Sebastião, an oil terminal (Dutos e Terminais Centro Sul DTCS) (Zanardi et al. 1999), and two submarine outfalls (one on the mainland, near the harbor at the Araçá Bay, and another at Saco da Capela, in Ilhabela municipality) have increasingly contributed to local contamination by chemical compounds. Furthermore, much attention has been given to this area due to an expansion of the harbor at São Sebastião, which requires information about environmental impact to marine ecosystems at the region (Teodoro et al. 2010).

In this context, all knowledge on ecological dynamics of coastal and oceanic areas represents important contributions to the evaluation and monitoring of environmental quality. New information is essential to planning and can draw attention to the preservation and sustainability of this delicate natural heritage in São Paulo State (Arasaki et al. 2004; Amaral et al. 2010; Teodoro et al. 2010).

São Sebastião Channel has been an important hub for scientific research due to its variety of habitats and biodiversity. Mollusks are conspicuous among the invertebrate groups found in this region (Amaral et al. 2010). Bivalves contribute to the conduction of nutrients from the pelagic to the benthonic zone, are considered key elements in trophic chains and are commercially relevant. Estimates suggest that there are about 1,000 marine bivalve species in Brazil; approximately 300 of these are believed to occur in São Paulo State, but only 191 were published (Simone 1999).

Despite the importance of bivalves in the marine environment, there are few details on their distribution, especially on those species living subtidally at greater depths. Malacofaunal studies in the São Sebastião Channel include the pioneer survey of Ihering (1897), as well as the study of Migotto et al. (1993), which analyzed several locations along the channel, and the investigation of Salvador et al. (1998), which focused on the centralnorthern beaches of Ilhabela.

Considering the absence of current data on bivalve diversity and distribution within the intertidal and subtidal zones of the north coast of the São Paulo State, this work aims to present an updated list of bivalve species within the São Sebastião Channel.

\section{Materials And Methods}

São Sebastião Channel is located between the municipalities of São Sebastião and Ilhabela on the north coast of São Paulo State, southeast Brazil; it is $25 \mathrm{~km}$ long, 2-7 km wide and up to $40 \mathrm{~m}$ deep in the central area (Netto et al. 2005; Oliveira et al. 2010). The climate is subtropical and water temperatures oscillate from 15 to $20^{\circ} \mathrm{C}$ (Migotto et al. 2001).

The bivalves were obtained from sediment samples collected in the intertidal and subtidal zones between January 2010 and December 2012. Only living specimens with soft parts were considered in this survey. 
Anomalocardia brasiliana, a species with great ecological and socioeconomic importance, was not included in this study, despite the huge biomass and conspicuous populations in certain sampling localities such as Araçá Bay. This species has a high nutritional value and supplies food for local fishermen and tourists (Amaral et al. 2010). Anomalocardia brasiliana was excluded from the present study because it has been investigated in other studies (Narchi 1974; Arruda-Soares et al. 1982; Boehs 2000; Arruda and Amaral 2003; Amaral 2010; Boehs et al. 2010).

A Global Positioning System device (Garmin GPSMAP 60CSx) was used to record positions of the stations. Intertidal sediment samples were collected using shovels and $0.5 \mathrm{~mm}$ sieve mesh. Samples were gathered on four different dates at Araçá Beach (2349.053' S, 4524.373' W), three different dates at Barequeçaba Beach $\left(23^{\circ} 49^{\prime}\right.$ S, $45^{\circ} 25^{\prime} \mathrm{W}$ ), both in São Sebastião, as well as twice at Velho Barreiro Beach $\left(23^{\circ} 45^{\prime} \mathrm{S}, 45^{\circ} 20^{\prime} \mathrm{W}\right)$ and once at the

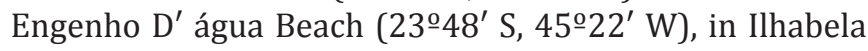
(Figure 1). Subtidal bottom samples were obtained using a Van Veen-type floor sediment collector, towed from a trawl boat. Subtidal samples were washed and sieved over 0.3 and $0.5 \mathrm{~mm}$ mesh sizes. The following subtidal localities were sampled once: two locations at 200 meters from the Figueira Pier in São Sebastião (234 $45.138^{\prime}$ S, $45^{\circ} 24.070^{\prime}$ W and $23^{\circ} 45^{\prime} \mathrm{S}, 45^{\circ} 24^{\prime} \mathrm{W}$ ), two stations in the middle of the
Channel, between São Sebastião and Ilhabela $\left(23^{\circ} 46.745^{\prime}\right.$ S, $45^{\circ} 23.091^{\prime} \mathrm{W}$ and $23^{\circ} 43.887^{\prime} \mathrm{S}, 45^{\circ} 22.420^{\prime} \mathrm{W}$ ), two stations at the Araçá Bay $\left(23^{\circ} 49.002^{\prime} \mathrm{S}, 45^{\circ} 24.159^{\prime} \mathrm{W}\right.$ and $23^{\circ} 48.872^{\prime} \mathrm{S}, 45^{\circ} 23.990^{\prime} \mathrm{W}$ ), one station near the Cigarras Beach, São Sebastião $\left(23^{\circ} 43.760^{\prime} \mathrm{S} 45^{\circ} 23.771^{\prime} \mathrm{W}\right)$ and one station at the Azeda Beach, Ilhabela $\left(23^{\circ} 44.622^{\prime} \mathrm{S}\right.$, $45^{\circ} 20.961^{\prime} \mathrm{W}$ ) (Figure 1).

All specimens were immediately submersed in seawater and kept alive for transport to the Marine Biology Center, São Paulo University (CEBIMar-USP), where they were dissected for other purposes. Foot and adductor muscle tissues were fixed in 95\% alcohol for molecular analyses and gonads were prepared for electron/light microscopy. The remaining soft parts and shells of the voucher specimens were deposited in the Museum of Zoology "Prof. Dr. Adão José Cardoso" (ZUEC), in the State University of Campinas (Table 1). Species identifications were based on Rios (1994, 2009), Mikkelsen and Bieler (2008), Quast (2003), Arruda (2005), Amaral et al. (2006), and Denadai et al. (2006), while suprageneric nomenclature and taxonomic order follow Bieler et al. (2010).

Images of shells were made using a stereomicroscope (Stereo Discovery V8, Carl Zeiss Microscopy) and a Canon digital camera (Figures 2-4). Some specimens were slightly damaged during dissection and other, well-preserved specimens from the teaching collection of State University

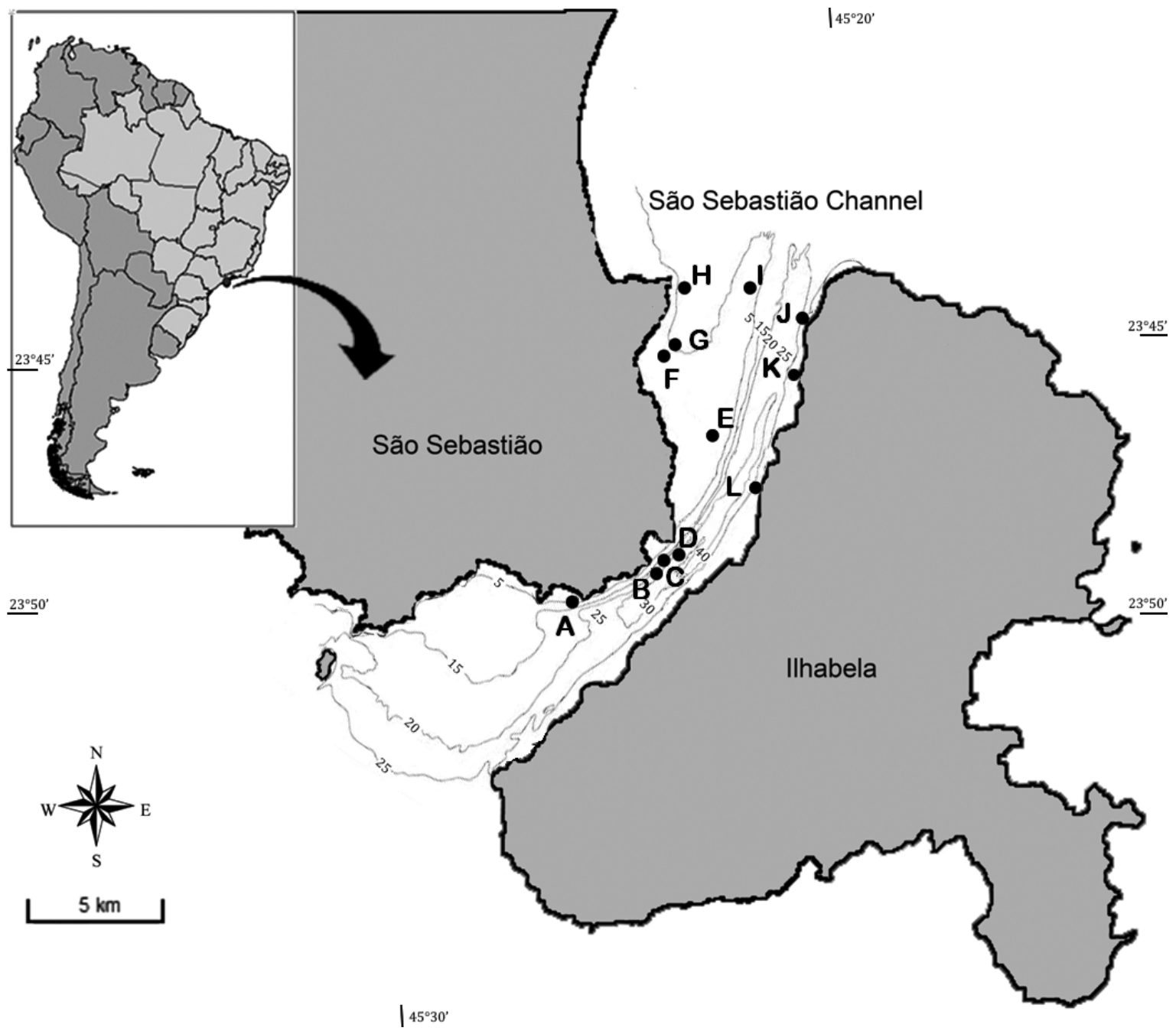

FigurE 1. Collection stations on the northern coast of the São Paulo State: (A) Barequeçaba Beach; (B) Araçá Beach; (C and D) Araçá Bay; (E and I) São Sebastião Channel; (F and G) São Sebastião Channel near Figueira Pier; (H) Cigarras Beach; (J) Azeda Beach; (K) Velho Barreiro Beach; (L) Engenho D’água Beach. 
of Campinas were photographed instead. However, all rare specimens collected as part of this study were all photographed.

\section{RESULTS}

Altogether 388 living individuals and 52 species of bivalves were collected. They belong to 34 genera, grouped in 18 families and five orders (Table 1, Figures 2-4).

A total of 330 specimens belonging to 43 species were found in the intertidal zone, while 58 specimens belonging to 22 species were found in the subtidal zone. The most frequently collected bivalve families were, in diminishing order of number of species: Tellinidae, Veneridae, Semelidae, Ungulinidae, Mactridae, Solecurtidae, Corbulidae, Cardiidae, Lucinidae, Cooperellidae, Nuculidae, Psammobiidae, Donacidae, Solenidae, Periplomatidae, Thraciidae and Arcidae. The most speciose families in both intertidal (Figure 5A) and subtidal (Figure 5B) zones were Tellinidae and Veneridae.

The abundant species exclusively found within the intertidal zone were Diplodonta punctata (Figure 2.8) at Velho Barreiro Beach, Codakia pectinella (Figure 2.6) at Engenho D'água Beach, and Caryocorbula caribaea (Figure 3.48) at Araçá Beach. However, the most abundant species in the subtidal zone, during one collection event, were Macoma uruguayensis (Figure 2.22) and Pitar fulminata (Figure 3.42).

A few species were exclusively found in the subtidal zone: Anadara chemnitzi (Figure 2.3), Anatina anatina (Figure 3.45), Caryocorbula chittyana (Figure 4.49), Chione subrostrata (Figure 3.38), Cyclinella tenuis (Figure 3.39), Juliacorbula aequivalvis (Figure 4.50), Macoma uruguayensis, Solecurtus sanctaemarthae (Figure 2.17), Strigilla producta (Figure 3.25) and Tellina trinitatis (Figure 3.30). Others were distributed both in the subtidal and intertidal zones: Chione cancellata (Figure 3.35), Chione paphia (Figure 3.36), Pitar fulminata, Tellina exerythra (Figure 3.27), Tellina versicolor (Figure 3.32), Abra lioica (Figure 2.12), Tagelus divisus (Figure 2.18), Caryocorbula caribaea, Laevicardium brasilianum (Figure 2.4), Codakia pectinella (Figure 2.6), Cooperella atlantica (Figure 3.44) and Nucula semiornata (Figure 2.1).

Sanguinolaria sanguinolenta (Figure 2.11) and Donax gemmula (Figure 2.16) were only found at the Barequeçaba Beach. Large numbers of Strigilla carnaria (Figure 2.23) and Strigilla pisiformis (Figure 2.24) were also found on this beach.

Araçá Bay is formed by sand and mud sediments and is one of the last remaining mangrove locations in the region. The bay has a high number of species. In six collections 93 individuals belonging to 22 species were found.

The collections from Engenho D'água Beach (one station) and Velho Barreiro Beach (two stations) show a large number of species. At Engenho D'água Beach, 108 specimens belonging to 19 species were found. At Velho Barreiro Beach, 72 specimens belonging to 15 species were collected.

\section{DISCUSSION}

Ecological studies on bivalves from the southeastern Brazilian coast found between 45 and 90 species in each area studied (Ihering 1897; Migotto 1993; Salvador et al. 1998; Soares-Gomes and Pires-Vanin 2003). Ihering (1897) collected 79 species in São Sebastião and Ilhabela. Migotto (1993) described 87 species collected in southern São Sebastião Channel, from Ponta do Guaecá to Araçá Bay. Salvador (1998) found 52 species from Barra Velha, Perequê and Engenho D'água beaches. Soares-Gomes and Pires-Vanin (2003) collected 59 samples from the Ubatuba continental shelf. In the present study, 52 species were found in São Sebastião Channel (Table 1), but differing collection methodologies and different locations do not allow in-depth comparison with earlier studies.

No new species were found during the present study, but some uncommon species were collected, including Anadara chemnitzi, Cooperella atlantica, Pitar circinata, Sanguinolaria sanguinolenta, Strigilla pisiformis, Solecurtus sanctaemarthae and Thracia similis (Figure 4.51) (Coltro 1997). Ihering (1897) recorded Sanguinolaria sanguinolenta and Strigilla pisiformis at Ilhabela beaches, but these species were only found at the Barequeçaba Beach in this survey. Some species collected in the present study but not found by Migotto et al. (1993) and Salvador et al. (1998) were: Anatina anatina, Caryocorbula chittyana, Codakia pectinella, Cooperella atlantica, Felaniella candeana (Figure 2.9), Juliacorbula aequivalvis, Periploma ovatum (Figure 4.52), Sanguinolaria sanguinolenta, Solecurtus sanctaemarthae, Strigilla pisiformis and Strigilla producta.

Due to possibly insufficient search effort at some sites, species previously reported in other studies were not found. The absence of such species in our data does not necessarily show that they are no longer extant in the area. Thus, we cannot state that the absence of certain species in our survey represents a reduction in biodiversity.

Willig et al. (2003) and Ricklefs (2004) suggest a pluralistic approach to study biodiversity, considering that there is not a universal criterion to measure it within a specified geographic area. Factors that influence biodiversity are not fully understood, although weather, climate stability, spatial heterogeneity, physical disturbances of the environment, sediment type, competition, predation and productivity are likely important. More heterogeneous environments are related to higher species richness (Soares-Gomez and Pires-Vanin 2003).

Water current and sediment type may contribute to the distribution of bivalve species in São Sebastião Channel. Seasonal dynamics of water masses in the channel greatly influences the marine biota (Migotto et al. 2001). Some localities contain a wide range of sediment sizes from sand and gravel grain classes to silt or clay, and this heterogeneity has been related to abundance of bivalves (Denadai et al. 2005). Araçá Bay, Engenho D’água and Velho Barreiro beaches have these heterogeneous sediments and favorable water currents.

The data in this study serve as a baseline for future investigations of the malacofauna of São Sebastião Channel. These results will be useful in preparing management plans for the preservation of this natural heritage. In addition, these data are important because they add to the general malacological knowledge of the northern coast of São Paulo State. 


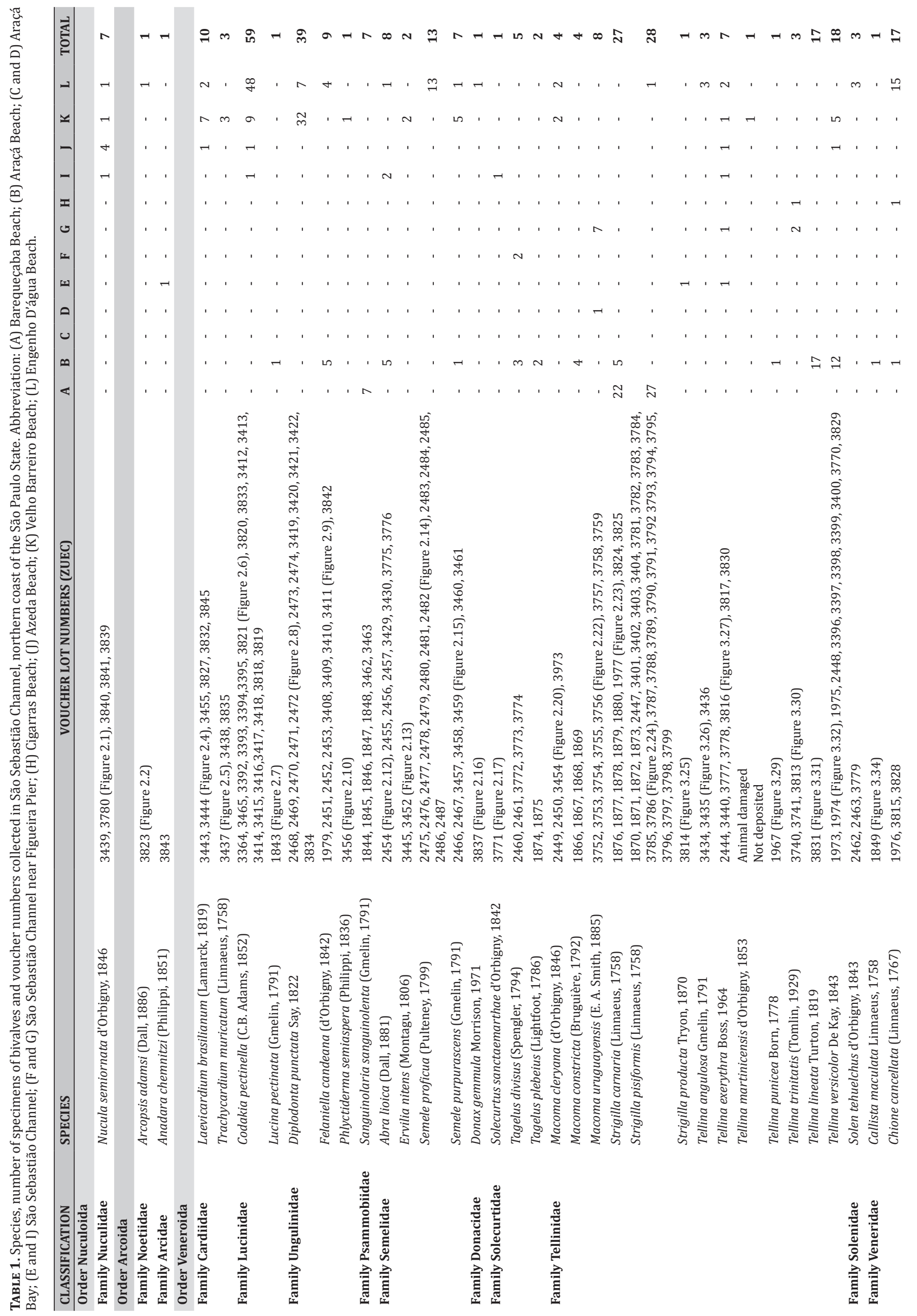




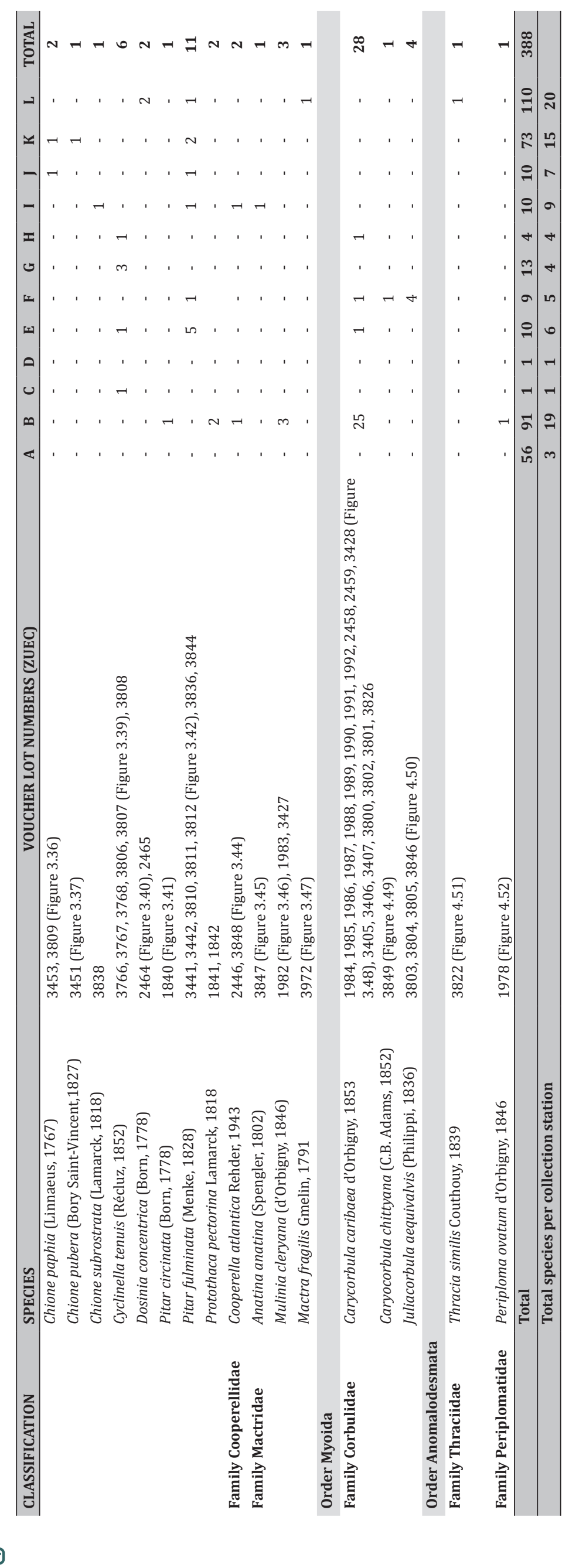



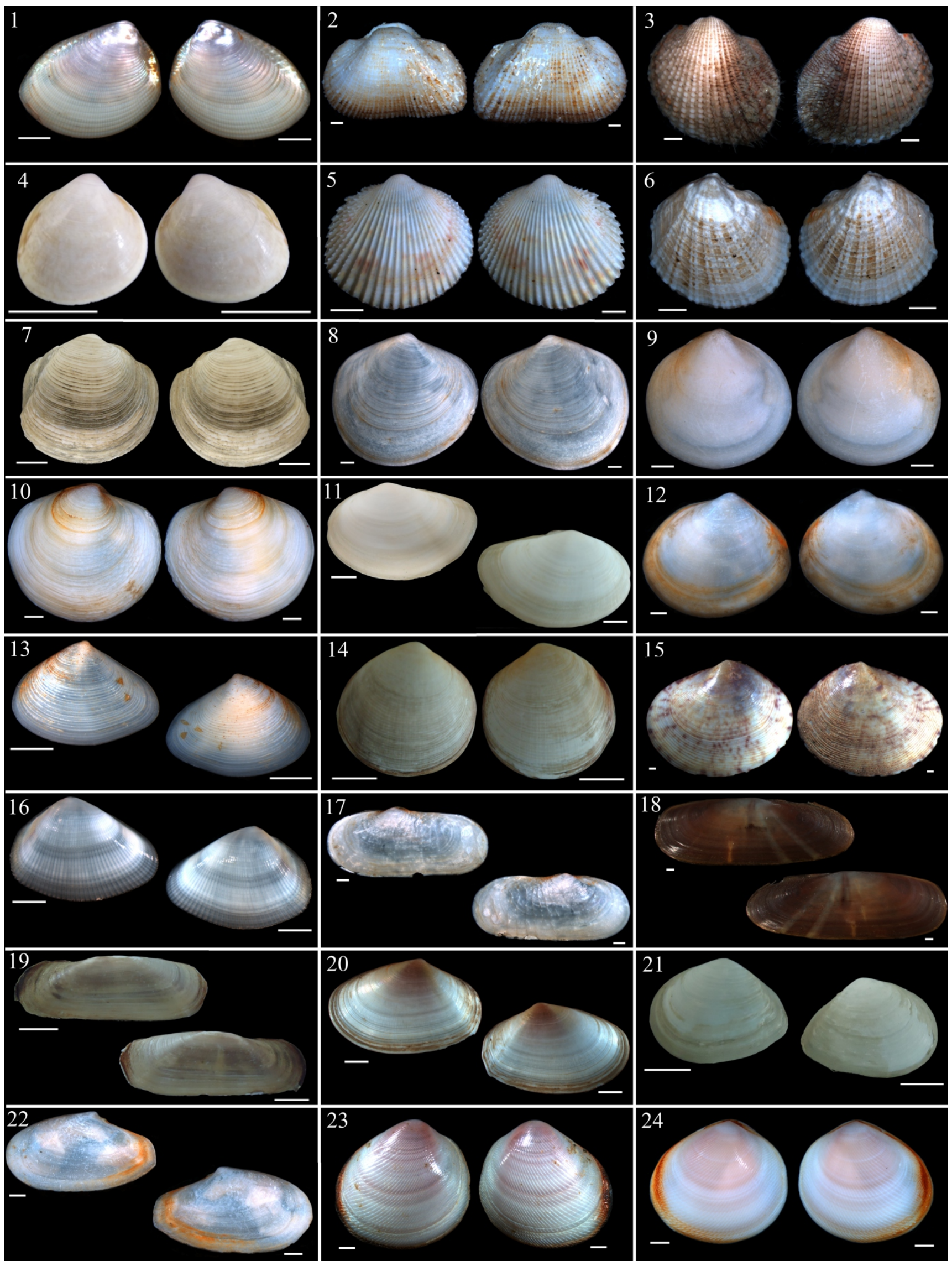

FIGURE 2. External view of right and left valves of the bivalves collected on the northern coast of the São Paulo State. (1) Nucula semiornata - ZUEC 3780; (2) Arcopsis adamsi - ZUEC 3823; (3) Anadara chemnitzi - TC; (4) Laevicardium brasilianum - ZUEC 3444; (5) Trachycardium muricatum - ZUEC 3437; (6) Codakia pectinella - ZUEC 3821; (7) Lucina pectinata - ZUEC 1843; (8) Diplodonta punctata - ZUEC 2472; (9) Felaniella candeana - ZUEC 3411; (10) Phlyctiderma semiaspera - ZUEC 3456; (11) Sanguinolaria sanguinolenta - TC; (12) Abra lioica - ZUEC 2454; (13) Ervilia nitens - ZUEC 3452; (14) Semele proficua - ZUEC 2482; (15) Semele purpurascens - ZUEC 3459; (16) Donax gemmula - ZUEC 3837; (17) Solecurtus sanctaemarthae - ZUEC 3771; (18) Tagelus divisus - TC; (19) Tagelus plebeius - TC; (20) Macoma cleryana - ZUEC 3454; (21) Macoma constricta - TC; (22) Macoma uruguayensis - ZUEC 3756; (23) Strigilla carnaria - ZUEC 1977; (24) Strigilla pisiformis - ZUEC 3786. Scale bars: Figs. 1-6, 8-10, 12-13, 15-18 = 1 mm; Figs. 7, 11, 14, 19 and $21=1 \mathrm{~cm}$; Fig. $20=4 \mathrm{~mm}$. Abbreviations: TC, Teaching Collection of State University of Campinas; ZUEC (voucher lot number), Museum of Zoology "Prof. Dr. Adão José Cardoso". 

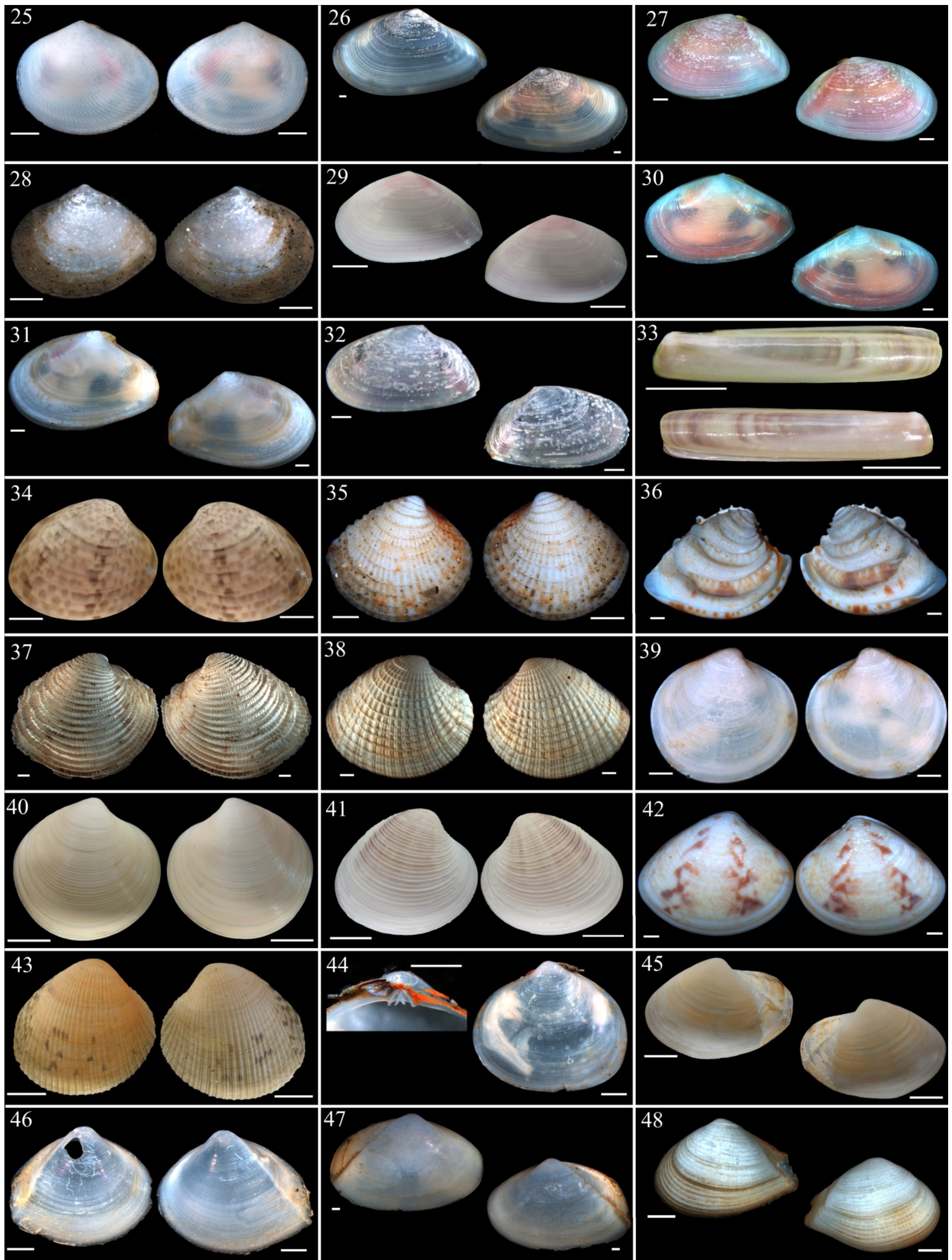

FIGURE 3. External view of right and left valves of the bivalves collected on the northern coast of the São Paulo State. (25) Strigilla producta - ZUEC 3814 (26) Tellina angulosa - ZUEC 3435; (27) Tellina exerythra - ZUEC 3816; (28) Tellina martinicensis - TC; (29) Tellina punicea - ZUEC 1967; (30) Tellina trinitatis - ZUEC 3813; (31) Tellina lineata - ZUEC 3831; (32) Tellina versicolor - ZUEC 1974; (33) Solen tehuelchus - TC; (34) Callista maculata - ZUEC 1849; (35) Chione cancellata - TC; (36) Chione paphia - ZUEC 3809; (37) Chione pubera - ZUEC 3451; (38) Chione subrostrata - TC; (39) Cyclinella tenuis - ZUEC 3807; (40) Dosinia concentrica - ZUEC 2464; (41) Pitar circinata - ZUEC 1840; (42) Pitar fulminata - ZUEC 3812; (43) Protothaca pectorina - TC; (44) Cooperella atlantica (right valve was damaged during the dissection, details of hinge plate of left valve) - ZUEC 3848; (45). Anatina anatina - ZUEC 3847; (46) Mulinia cleryana - ZUEC 1982; (47) Mactra fragilis - ZUEC 3972; (48) Carycorbula caribaea - ZUEC 3428. Scale bars: Figs. 25-32, 34-40, 42, 44 and 46-48 = $1 \mathrm{~mm}$; Figs. 33, 41, 43 and $45=1 \mathrm{~cm}$. Abbreviations: TC, Teaching Collection of State University of Campinas; ZUEC (voucher lot number), Museum of Zoology "Prof. Dr. Adão José Cardoso". 

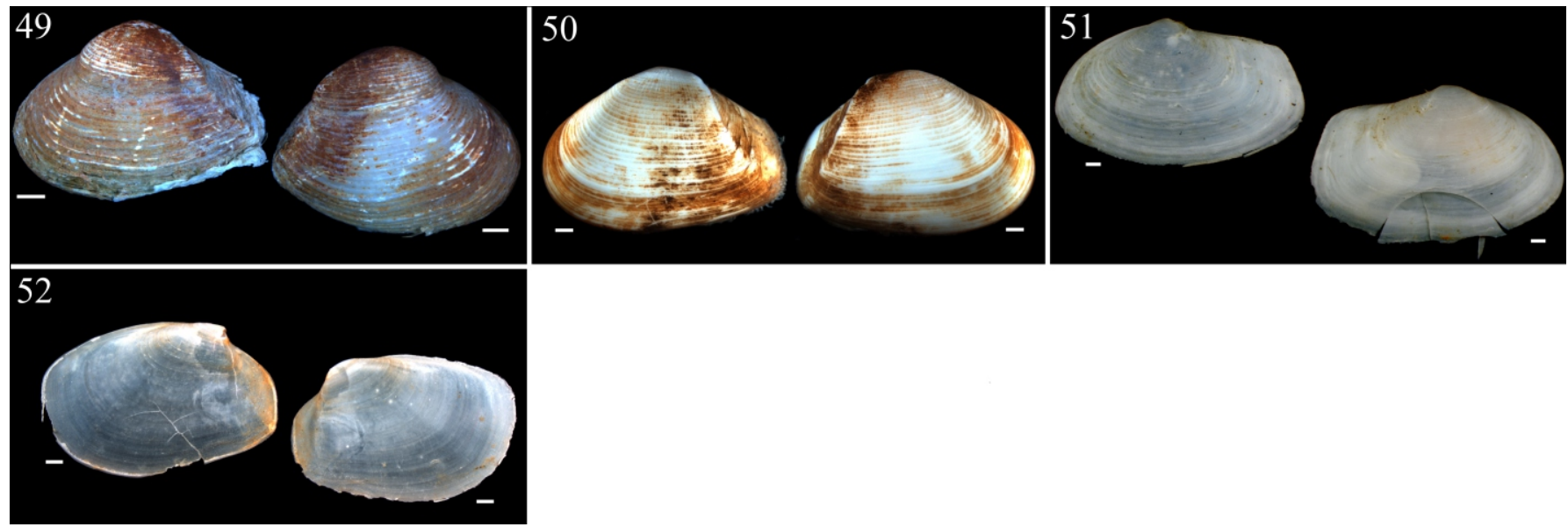

FIGURE 4. External view of right and left valves of the bivalves collected on the northern coast of the São Paulo State. (49) Caryocorbula chittyana - ZUEC 3849; (50) Juliacorbula aequivalvis - ZUEC 3846; (51) Thracia similis - ZUEC 3822; (52) Periploma ovatum - ZUEC 1978. Scale bars: $1 \mathrm{~mm}$. Abbreviations: TC, Teaching Collection of State University of Campinas; ZUEC (voucher lot number), Museum of Zoology “Prof. Dr. Adão José Cardoso".

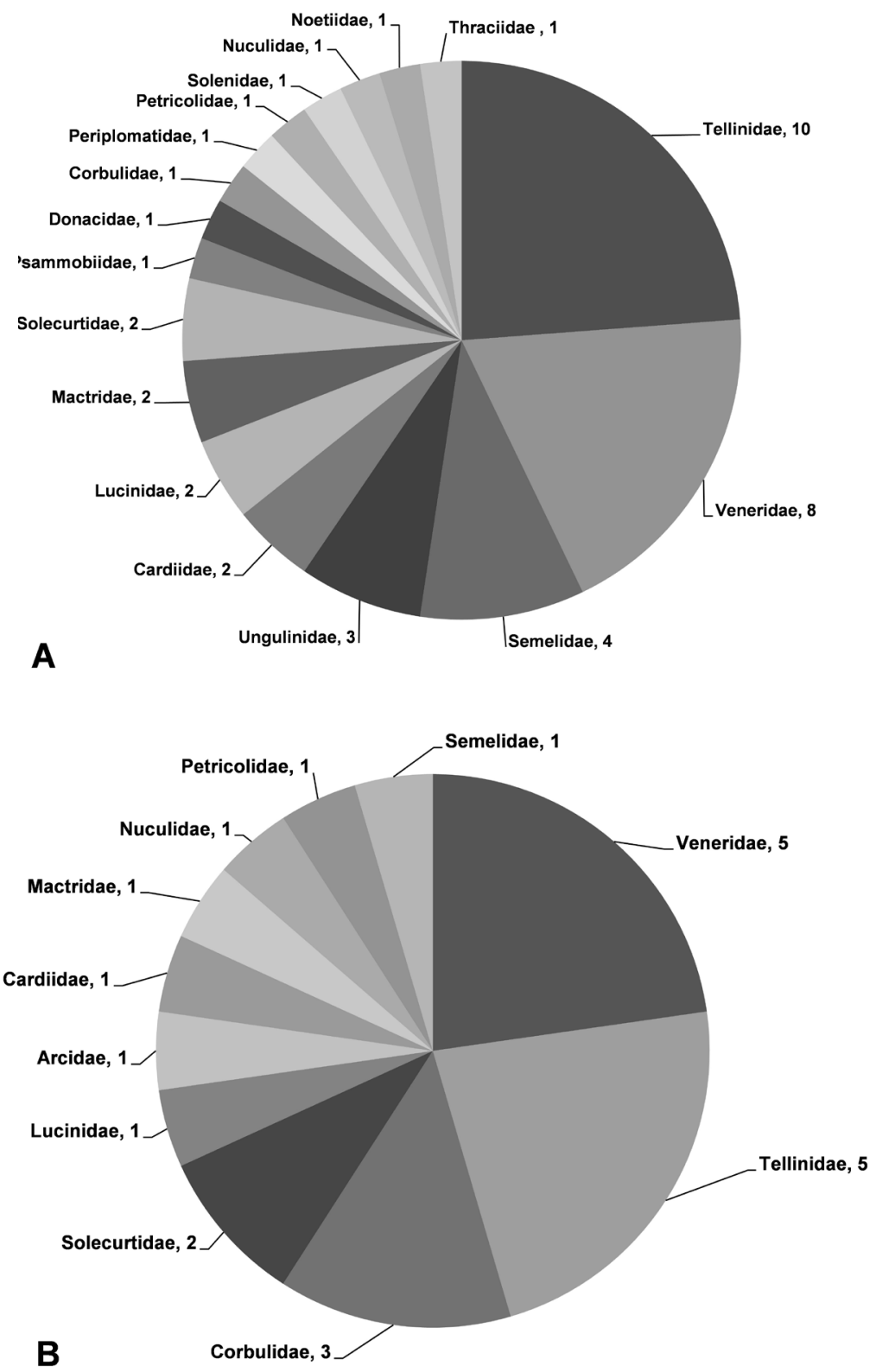

FIGURE 5. (A) Total of species per family collected in the intertidal zones of the São Sebastião and Ilhabela beaches, between 2010 and 2012. (B) Total of species per family of bivalves collected in 2012 in locations within the São Sebastião Channel. 
ACKNOWLEDGMents: The study was supported by São Paulo Research Foundation (FAPESP) and Coordination for the Improvement of Higher Education Personnel (CAPES). The National Council for Scientific and Technological Development (CNPq) is acknowledged for the scholarship of A.C and CAPES for the scholarship of F. M. M. The authors thank the Marine Biology Center, University of São Paulo (CEBIMar-USP), for facilitating the specimen gathering, and the referees, especially Robert G. Forsyth, for the critical review.

\section{LITERATURE CITED}

Amaral, A.C.Z., A.E. Migotto, A. Turra and Y. Schaeffer-Novelli. 2010. Araçá: biodiversidade, impactos e ameaças. Biota Neotropica 10(1): 219-264.

Amaral, A.C.Z., A.E. Rizzo and E.P. Arruda. 2006. Manual de identificação dos invertebrados marinhos da região sudeste-sul do Brasil. Volume I. São Paulo: Editora Universidade de São Paulo, São Paulo. 288 pp.

Arruda, E.P. 2005. Mollusca Bivalvia (Veneroida) da costa sudeste do Brasil. PhD Thesis. São Paulo: Universidade de São Paulo. 266 pp.

Arruda, E.P. and A.C.Z. Amaral. 2003. Spatial distribution of mollusks in the intertidal zone of sheltered beaches in southeastern of Brazil. Revista Brasileira de Zoologia 20(2): 291-300.

Arruda-Soares H., Y. Schaeffer-Novelli and J. Mandelli Jr. 1982. "Berbigão" Anomalocardia brasiliana (Gmelin, 1791), bivalve comestível da região da Ilha do Cardoso, Estado de São Paulo, Brasil: aspectos biológicos de interesse para a pesca comercial. Boletim do Instituto de Pesca 9: 21-38.

Arasaki, E., P. Muniz and A.M.S. Pires-Vanin. 2004. A functional analysis of the benthic macrofauna of the São Sebastião Channel (southeastern Brazil). Marine Ecology 25(4): 249-263.

Bieler, R., J.G. Carter and E.V. Coan. 2010. Classification of bivalve families. Malacologia 52(2): 113-133.

Boehs, G., 2000. Ecologia populacional, reprodução e contribuição em biomassa de Anomalocardia brasiliana (Gmelin, 1791) (Bivalvia: Veneridae) na Baía de Paranaguá, Paraná, Brasil. PhD Thesis. Curitiba: Universidade Federal do Paraná. 201 pp.

Boehs, G., A.Villalba, L.O. Ceuta and R.J. Luz. 2010. Parasites of three commercially exploited bivalve mollusc species of the estuarine region of the Cachoeira river (Ilhéus, Bahia, Brazil). Journal of Invertebrate Pathology 103(1): 43-47.

Coltro, J. 1997. 15 Years Collecting Around São Sebastião, São Paulo, Brazil. Accessible at http://www.conchologistsofamerica.org/articles/ y1997/9712 coltro.asp. Captured on 16 December 2013.

Denadai, M.R., A.C.Z. Amaral and A. Turra. 2005. Structure of molluscan assemblages in sheltered intertidal unconsolidated environments. Brazilian Archives of Biology and Technology 48(5): 825-839.

Denadai, M.R., E.P. Arruda, O. Domaneschi and A.C.Z. Amaral. 2006. Veneridae (Mollusca, Bivalvia) da costa norte do Estado de São Paulo, Brasil. Biota Neotropica 6(3): 1-34.

Ihering, H. von. 1897. A Ilha de São Sebastião. Revista do Museu Paulista 2: 129-171.

Migotto, A.E., A.C. Marques, M.N. Flynn, 2001. Seasonal recruitment of hydroids (Cnidaria) on experimental panels at São Sebastião Channel, southeastern Brazil. Bulletin of Marine Science 68(2): 287-298.
Migotto, A.E., C.G. Tiago and A.R.M. Magalhães. 1993. Malacofauna marinha da região costeira do Canal de São Sebastião, SP, Brasil: Gastropoda, Bivalvia, Polyplacophora e Scaphopoda. Boletim do Instituto Oceanográfico 41(1/2): 13-27.

Mikkelsen, P.M. and R. Bieler. 2008. Seashells of Southern Florida: Living Marine Mollusks of the Florida Keys and Adjacent Regions. Princeton: Princeton University Press. 503 pp.

Narchi, W. 1974. Aspectos ecológicos e adaptativos de alguns bivalves do litoral paulista. Papéis Avulsos de Zoologia 27: 235-262.

Netto, L.F., V.F. Hadel and C.G. Tiago. 2005. Echinodermata from São Sebastião Channel (São Paulo, Brazil). Revista de Biologia Tropical 53(3): 207-218.

Quast, M.P. 2003. Moluscos Bivalves (Arcoida e Ostreoida) da Costa Sudeste do Brasil. Master's Thesis, University of Campinas, Campinas. 128 pp.

Oliveira, O.M.P., A.E. Migotto and A.C. Marques. 2010. Ctenophores from the São Sebastião Channel. Accessible at http://www.usp.br/cbm/ ctenophora. Captured on 18 March 2013.

Ricklefs, R.E. (2004). A comprehensive framework for global patterns in biodiversity. Ecology Letters 7: 1-15.

Rios, E.C. 1994. Seashells of Brazil, 2 ${ }^{\text {nd }}$ ed. Rio Grande: Fundação Universidade do Rio Grande. 368 pp.

Rios, E.C. 2009. Compendium of Brazilian Sea Shells. Rio Grande: Evangraf. $668 \mathrm{pp}$.

Salvador, L.B., O. Domaneschi, A.C.Z. Amaral, E.H. Morgado and S.A. Henriques. 1998. Malacofauna da região entremarés de praias da Ilha de São Sebastião (São Paulo, Brasil). Revista Brasileira de Zoologia 15(4): 1013-1035.

Simone, L.R.L. 1999. Filo Mollusca; pp. 129-136, in: A.E. Miggoto and C.G. Tiago (ed.). Biodiversidade do Estado de São Paulo: síntese do conhecimento ao final do século XX, 3: invertebrados marinhos. São Paulo: Fundação de Amparo à Pesquisa do Estado de São Paulo.

Soares-Gomez, A. and A.M.S. Pires-Vanin. 2003. Padrões de abundância, riqueza e diversidade de moluscos bivalves na plataforma continental ao largo de Ubatuba, São Paulo, Brasil: uma comparação metodológica. Revista Brasileira de Zoologia 20(4): 717-725.

Teodoro, A.C., W. Duleba, S. Gubitoso, S.M. Prada, C.C. Lamparelli and J.E. Bevilacqua. 2010. Analysis of foraminifera assemblages and sediment geochemical properties to characterize the environment near Araçá and Saco da Capela domestic sewage submarine outfalls of São Sebastião Channel, São Paulo State, Brazil. Marine Pollution Bulletin 60(4): 536-553.

Willig, M.R., D.M. Kaufman and R.D. Stevens. 2003. Latitudinal gradients of biodiversity: pattern, process, scale, and synthesis. Annual Review of Ecology, Evolution, and Systematics 34: 273-309.

Zanardi, E., M.C. Bícego, L.B. Miranda and R.R. Weber. 1999. Distribution and origin of hydrocarbons in water and sediment in São Sebastião, SP, Brazil. Marine Pollution Bulletin 38(4): 261-267.

RECEIVED: August 2013

ACCEPTED: December 2013

Published ONLINE: February 2014

EDITORIAL RESPONSIBILITY: Robert Forsyth 